\title{
Sickle cell anaemia and the NBT test
}

\author{
THOMAS R. WALTERS 1 AND B. NARASIMHA REDDY
}

From the Department of Paediatrics, New Jersey Medical School, Newark, New Jersey, USA

SYNOPSIS Patients with sickle cell anaemia have an increased susceptibility to bacterial infections Previous reports of false-negative nitro blue tetrazolium (NBT) tests in the presence of bacteria infection and of a faulty phagocytic response following stimulation in vitro have suggested the possibility of polymorphonuclear dysfunction in certain patients with sickle cell anaemia.

In the present study an unstimulated, histochemical NBT technique was used to evaluate the test in patients with sickle cell anaemia. There was a significant difference between the results in the group of patients with infection (mean NBT-positive cells $42.7 \%$ ) compared to those without infection (mean $9.4 \%$ ). There was no significant correlation between the total white blood cell count, absolute number of polymorphonuclear cells, and infectious complications.

These findings indicate an appropriate polymorphonuclear cell response, as evaluated by the NBT test, in patients with sickle cell anaemia and bacterial infection. The NBT test may be used as an additional parameter in the differentiation of those patients with sickle cell anaemia with bacterial infection.

Patients with sickle cell anaemia have an increased susceptibility to bacterial infections. Although infections such as salmonella osteomyelitis (Hook, Campbell, Weens, and Cooper, 1957) and pneumococcal meningitis (Robinson and Watson, 1966) have been most commonly reported, in a review of bacterial infections in patients with sickle cell anaemia numerous other organisms were identified (Barrett-Connor, 1971). The reduction of nitro blue tetrazolium (NBT) to formazan by polymorphonuclear cells has been previously reported as a finding suggestive of systemic bacterial infection (Park, Figrik, and Smithwick, 1968; Feigin, Shackelford, and Choi, 1971). Reports of a false negative NBT test, that is, absence of reduction of NBT in the presence of bacterial infections in patients with sickle cell anaemia (Park, 1971; Humbert, Marks, Hathaway, and Thoren, 1972), suggested the possibility of a defect in polymorphonuclear function in these patients as an additional predisposing defect related to the increased susceptibility to bacterial infections. A report of an inappropriate response in vitro following phagocytic stimulation of polymorphonuclear cells in certain patients with sickle cell anaemia supported this possibility

\footnotetext{
${ }^{1}$ Address for reprints: Thomas R. Walters, MD, New Jersey Medical School, Department of Paediatrics, 100 Bergen Street, Newark, New Jersey, 07103

Received for publication 8 July 1974.
}

(Dimitrov, Douwes, Bartolotta, Nochumson, and Toth, 1972). These findings suggested that the predictive value of the NBT test would be limited in patients with sickle cell anaemia. The purpose of the present study was to evaluate the NBT test in patients with sickle cell anaemia and to determine its possible usefulness in identifying the presence of bacterial infections in these patients.

\section{Methods}

A modified spontaneous dye reduction test by peripheral blood neutrophils was used (Park, Fikrig, and Smithwick, 1968). Heparinized blood, 10 units $/ 100 \mathrm{ml}$, was drawn through a scalp vein catheter. One hundred lambda of fresh whole blood was incubated in a plastic cup with 100 lambda of $0.2 \%$ NBT suspended in $0.9 \%$ saline for 15 minutes at $37^{\circ}$ and for 15 minutes at room temperature. Coverslip slides were made and 200 polymorphonuclear cells were evaluated. Polymophonuclear cells were interpreted as NBT positive if black-bluereduced formazan was present within the cells. When the test was markedly positive, ie, greater than $25 \%$, clumping of NBT-positive cells was noted, a finding previously reported (Neuwirtová, 1973). These clumps were disregarded and only single polymorphonuclear cells were included in the differential count. The results were evaluated 
separately by two investigators without knowledge of the patient's condition or the results of other laboratory procedures. There was a consistent agreement in the interpretation of the morphological findings. The data were then correlated with the clinical, radiological, and bacteriological findings. Haematological studies were performed by standard techniques. The Student $t$ test was used to calculate $P$ values.

\section{Results and Discussion}

There is an increased susceptibility to bacterial infections in patients with sickle cell anaemia. Several predisposing defects have been described: (1) splenic dysfunction has been demonstrated in children with sickle cell anaemia, which is reversible by transfusion of haemoglobin A blood (Pearson, Spencer, and Cornelius, 1969;Pearson, Cornelius, and Schwartz, 1970); (2) an impaired antibody response following the intravenous injection of sheep erythrocytes has further incriminated splenic dysfunction (Schwartz and Pearson, 1972); and (3) a deficiency in heat-labile serum opsonizing activity (Winkelstein and Drachman, 1968), and an abnormality in the alternate pathway of complement activation have also been reported (Johnson, Newman, and Struth, 1973).

Several reports have suggested a defect in polymorphonuclear cell dysfunction in these patients. False negative NBT tests have been reported in patients with sickle cell anaemia and bacterial infections such as pneumococcal meningitis (Park, 1971) and salmonella osteomyelitis (Humbert et al, 1972). In addition, a subgroup of patients with sickle cell anaemia has been reported to have a defect in polymorphonuclear cell response following phagocytic stimulation in vitro (Dimitrov et al, 1972). Eight of 13 patients having this abnormality had a history of repeated infections. The five who had an appropriate response were adult patients who had no history of infection.

In contrast to these reports we found a mean of $39.7 \% \pm 4.1 \%$ NBT positive polymorphonuclear cells in nine patients with sickle cell anaemia and

\begin{tabular}{llll}
\hline $\begin{array}{l}\text { Sickle Cell } \\
\text { Anaemia }\end{array}$ & $\begin{array}{l}\text { No. of } \\
\text { Patients }\end{array}$ & $\begin{array}{l}\text { Mean Percentage } \\
\text { Positive PMN Cells }\end{array}$ & P Value \\
\hline Controls & 24 & $11 \cdot 0 \pm$ SE 1.1 & NS \\
In crisis & 22 & $7 \cdot 8 \pm 1 \cdot 1$ & $<0.01$ \\
With pneumonia & 9 & $39 \cdot 7 \pm 4 \cdot 1$ & $<0.01$ \\
With septicemia & 5 & $45 \cdot 7 \pm 6.6$ & \\
\hline
\end{tabular}

Table I Sickle cell anaemia and the NBT test

'The $P$ value was used to compare the results with the haematologically normal controls, who had no evidence of infection. pneumonia (table I). This was significantly greater than the occurrence of NBT-positive cells in normal individuals without a haemoglobinopathy or in- fection $(11 \pm 1 \cdot 1 \%, P<0.01)$. Although pul- $\underset{\overrightarrow{\mid}}{\overrightarrow{\mid}}$ monary infarction is reported as a frequent com- -0 plication in patients with sickle cell anaemia (Diggs, 음 1965), our results do not differentiate between a primary bacterial pneumonia and a secondary $\underset{\Omega}{\overparen{Q}}$ infection following infarction. In five patients with sickle cell anaemia and septicaemia the mean value ${ }^{\infty}$ of NBT-positive polymorphonuclear cells was. $45.7 \pm 6.6 \%(P<0.01)$.

In contrast to these findings, in 22 patients in sickle cell crisis without evidence of bacterialo infection, the NBT test showed a mean value of $\mathrm{i}$ $7.8 \%$ positive $\pm 1 \cdot 1 \%$. These results were similar. to the normal controls. Chest $x$-rays were done in $\vec{O}$ nine of these patients and were negative as were $\infty \mathrm{c}$ blood cultures in all.

Controversy exists in the value of the NBT test $\stackrel{\circ}{5}$ with both false negative and false positive results $\overrightarrow{0}$ (Park, 1971; Humbert et al, 1972). It was most recently reported that the use of the total white $\frac{0}{0}$ blood cell count, the number of immature poly- $\mathbb{\complement}$ morphonuclear cells, cytoplasmic granulation and $\vec{\varphi}$ vacuolization, and the presence of Döhle bodis were more sensitive indicators than the NBT test \&f the presence of systemic infection(Steibigel, Johnso and Remington, 1974). However, white blood cell counts in normal ambulatory children with sickle cell anaemia have been reported to average 20000 \% with a range of 12 to 35000 (Pearson and Diamond, 1971). As shown in table II, the total white blood

\begin{tabular}{|c|c|c|c|}
\hline $\begin{array}{l}\text { Clinical } \\
\text { Status }\end{array}$ & $\begin{array}{l}\text { No. of } \\
\text { Patients }\end{array}$ & Mean $\mathrm{WBC} / \mathrm{mm}^{3}$ & $\begin{array}{l}\text { Mean } \\
P M N / \mathrm{mm}^{2}\end{array}$ \\
\hline $\begin{array}{l}\text { Crisis } \\
\text { Pneımonia }\end{array}$ & $\begin{array}{r}22 \\
9\end{array}$ & $\begin{array}{l}16246 \pm \text { SE } 4868 \\
22587 \pm 12820 \\
(P=N S)\end{array}$ & $\begin{array}{l}10317 \pm 3800 \\
14271 \pm 7823 \\
(\mathbf{P}=\mathrm{NS})\end{array}$ \\
\hline Septicaemia & 5 & $\begin{array}{l}31360 \pm 15191 \\
(P=N S)\end{array}$ & $\begin{array}{c}23535 \pm 17969 \\
(P=N S)\end{array}$ \\
\hline
\end{tabular}

Table II Total white blood cell and absolute polymorphonuclear count in patients with sickle cell anaemia

The $\mathbf{P}$ value was calculated to compare the findings in pneumonia and septicaemia to episodes of painful thrombotic crisis without $N$ bacterial infections.

cell count and absolute number of polymorpho- $c$ nuclear cells were not significantly different between 2 patients in crisis without infection and those withe infection, either pneumonia or septicaemia. These results were not helpful in evaluating the presence of infection.

Our findings indicate that polymorphonuclear $\stackrel{\circ}{\overparen{D}}$

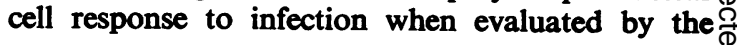


NBT test is appropriate in certain patients with sickle cell anaemia. They also suggest that the NBT test may be a useful adjunct to a comprehensive history and physical examination and other laboratory tests in the evaluation of bacterial infections in these patients.

\section{References}

Barrett- Connor, E. (1971). Bacterial infection and sickle cell anaemia. Medicine (Baltimore), 50, 97-112.

Diggs, L. W. (1965). Sickle cell crisis. Amer. J. clin. Path., 44, 1-19.

Dimitrov, N. V., Douwes, F. R., Bartolotta, B., Nochumson, S., and Toth, M. A. (1972). Metabolic activity of polymorphonuclear leukocytes in sickle cell anaemia. Acta haemat. (Basel), 47, 283-291.

Feigin, R. D., Shackelford, P. G., and Choi, S. C. (1971). Prospective use of the nitroblue tetrazolium dye test in febrile disorders. J. Pediat., 79, 943-947.

Hook, E. W., Campbell, C. G., Weens, H. S., and Cooper, G. R. (1957). Salmonella osteomyelitis in patients with sickle-cell anemia. New Engl. J. Med., 257, 403-407.

Humbert, J. R., Marks, M. I., Hathaway, W. E., and Thoren, C. H. (1972). The histochemical nitroblue tetrazolium reduction test in the differential diagnosis of acute infections. Pediatrics, 48, 259-267.

Johnston, R. B., Jr., Newman, S. L., and Struth, A. G. (1973). An abnormality of the alternate pathway of complement activation in sickle-cell disease. New Engl. J. Med., 288, 803-808.

Neuwirtová, R. (1973). NBT and cell clumping. New Engl. J. Med., 288, 970.

Park, B. H. (1971). The use and limitations of the nitroblue tetrazolium test as a diagnostic aid. J. Pediat. 78, 376-378.

Park, B. H., Fikrig, S. M., and Smithwick, E. M. (1968). Infection and nitroblue-tetrazolium reduction by neutrophils. Lancet, 2 , 532-534.

Pearson, H. A., Cornelius, E. A., Schwartz, A. D., Zelson, J. H., Wolfson, S. L., and Spencer, R. P. (1970). Transfusionreversible functional asplenia in young children with sickle-cell anemia. New Engl. J. Med., 283, 334-337.

Pearson, H. A., and Diamond, L. K. (1971). The critically ill child: sickle cell disease crises and their management. Pediatrics, 48, 629-635.

Pearson, H. A., Spencer, R. P., and Cornelius, E. A. (1969). Functional asplenia in sickle-cell anemia. New Engl. J. Med., 281, 923-926.

Robinson, M. G., and Watson, R. J. (1966). Pneumococcal moningitis in sickle-cell anemia. New Engl. J. Med., 274, 1006-1008.

Schwartz, A. D., and Pearson, H. A. (1972). Impaired antibody response to intravenous immunization in sickle-cell anemia. Pediat. Res., 6, 145-149.

Steigbigel, R. T., Johnson, P. K., and Remington, J. S. (1974). The nitroblue tetrazolium reduction test versus conventional hematology in the diagnosis of bacterial infection. New Engl. J. Med., 290, 235-238.

Winkelstein, J. A., and Drachman, R. H. (1968). Deficiency of pneumococcal serum opsonizing activity in sickle-cell disease. New Engl. J. Med., 279, 459-466. 